\title{
Endothelin-1 levels in induced sputum samples from asthmatic and normal subjects
}

\author{
George W Chalmers, Lorna Thomson, Kirsten J Macleod, Kenneth D Dagg, \\ Brian J McGinn, Charles McSharry, Kantilal R Patel, Neil C Thomson
}

Sputum induction has been developed as an alternative technique for sampling of airway secretions which, by contrast with bronchoscopy, is non-invasive, generally well tolerated, and can be repeated after a short interval if required. The objectives of the study were to establish whether ET-1 could be measured in fluid produced by sputum induction, to compare the levels of ET-1 in saliva, sputum and plasma, and to compare basal levels of ET1 in each fluid between asthmatic and nonasthmatic subjects.

\section{Methods}

SUBJECTS AND SPUTUM INDUCTION

Twenty eight stable asthmatics and nine normal subjects who were non-smokers were studied. Asthma was defined by clinical symptoms, response to inhaled $\beta_{2}$ agonist, and a methacholine $\mathrm{PC}_{20}$ of $<8 \mathrm{mg} / \mathrm{ml}$. Normal subjects were asymptomatic and had a methacholine $\mathrm{PC}_{20}$ of $>16 \mathrm{mg} / \mathrm{ml}$ with normal baseline spirometric measurements. The study was approved by the West Ethics Committee, West Glasgow Hospitals University NHS Trust, and each subject gave written informed consent.

Sputum induction was performed using a modification of the method described by Pin et $a .^{3}$ Briefly, after salbutamol $200 \mu \mathrm{g}$ was administered, saliva was collected over the next five minutes, followed by blood sampling and sputum induction using hypertonic (3\%) saline administered via an ultrasonic nebuliser (Schuco International Ltd, London, UK) over a period of 20 minutes. Samples were collected in sterile containers and transferred to the laboratory on ice, with laboratory staff not informed of clinical details. ET-1 in plasma samples did not alter as a result of sputum induction per se (subgroup $\mathrm{n}=9$, data not shown).

Keywords: asthma, endothelin, induced sputum.

Hospitals

University NHS Trust,

Western Infirmary, Glasgow G11 6NT, UK

Thistle Research, West of Scotland Science Park, Glasgow G20 0SP, UK B J McGinn

Correspondence to: Dr G W Chalmers. Received 20 September 1996

Returned to authors

20 November 1996

Revised version received

24 March 1997

Accepted for publication

24 March 1997
It is postulated that endothelins (ET) may have a role in the pathogenesis of asthma by various mechanisms, including direct bronchoconstriction, since ET-1 is one of the most potent bronchoconstrictor peptides yet isolated. ET1 is produced by human bronchial epithelial cells, and the bronchial epithelial cells of asthmatic patients, but not of normal subjects, show increased expression of endothelin. ${ }^{1}$ Elevated levels of endothelin have been reported in bronchoalveolar lavage fluid of symptomatic and non-steroid treated asthmatic patients. ${ }^{2}$

\section{LABORATORY PROCESSING}

Sputum plugs were selected (minimum $50 \mathrm{mg}$ ) to minimise salivary contamination and were split into two, half of which were treated with fresh dithiothreitol (DTT) (Sigma UK Ltd) in a balanced salt solution and used for cell counts and assay of eosinophilic cationic protein (ECP), and the other half were centrifuged at $13000 \mathrm{rpm}$ for 15 minutes without prior treatment with DTT for ET-1 assay as we found that DTT altered the standard curve for the ET-1 assay. Differential cell counts (Giemsa stained) were expressed after exclusion of squamous epithelial cells which were taken 
to represent salivary contamination. Reversed phase high performance liquid chromatography (RP-HPLC) was carried out on saliva and sputum samples. During the gradient elution $10 \times 1 \mathrm{ml}$ fractions were collected between 15 and 25 minutes (synthetic ET-1 elution point was 21.1 minutes). Endothelin was assayed using a radioimmunoassay (RIA) (Nichols Institute Diagnostics Ltd, San Juan Capistrano, California, USA) with a lower limit of detection of $1.6 \mathrm{pg} / \mathrm{ml}$ in plasma following pre-extraction using C-18 columns (Sep-pak, Waters Ltd Watford, UK). Recovery of ET-1 from sputum was $88 \%$. ECP was assayed using a radioimmunoassay with a lower limit of detection of $2 \mu \mathrm{g} / \mathrm{l}$ in plasma (Pharmacia UK Ltd, Milton Keynes, UK).

STATISTICAL ANALYSIS

Non-parametric statistics were used to compare cell counts, ECP, and ET-1 values. Significance was accepted at the 95\% level. Power calculations suggest a power of $>85 \%$ to detect a difference in sputum levels of ET-1 of \pm 1 SD.

\section{Results}

The asthmatic group was older (mean (SD) age 41.4 (10) years versus 31.8 (8.8) years), and had lower forced expiratory volume in one second $\left(\mathrm{FEV}_{1}\right)$ values than normal subjects, both as absolute values (2.99 (0.9) 1 versus $3.93(1.08) 1)$ and percentage predicted (84.0 (14)\% versus $99.2(11.4) \%)$. The mean daily dose of inhaled corticosteroid was $400 \mu \mathrm{g}$ beclomethasone or equivalent in the asthmatic group. The levels of eosinophils in the sputum were higher in the asthmatic group (median $3 \%$ ) than in the normal subjects (median $0 \%$ ), and no differences were seen in sputum volumes, total cell counts, or other cells. A comparison of median (IQR) plasma, saliva and sputum levels of ET-1 between each group showed no significant differences between asthmatic and normal subjects for each fluid (asthmatics, saliva $23.8(14.4-33.7) \mathrm{pg} / \mathrm{ml}$; sputum $11.2(9.4-18.9) \mathrm{pg} / \mathrm{ml}$; plasma $3.6(2.8-4.5) \mathrm{pg} /$ $\mathrm{ml}$ : normal subjects, saliva $30.1(20.1-43.4) \mathrm{pg} /$ $\mathrm{ml}$; sputum 15.5 (10.0-21.4) pg/ml; plasma 3.1 $(1.7-4.8) \mathrm{pg} / \mathrm{ml})$. Pairwise analysis of asthmatic subgroups revealed no differences between those taking inhaled steroids $(n=16)$ and those taking inhaled $\beta_{2}$ agonists alone $(n=$ 12). There were significant differences within each patient group in the levels of ET-1 in the order saliva $>$ sputum $>$ plasma (fig 1). No significant direct correlation was found between plasma or sputum levels of ET-1 and the $\mathrm{FEV}_{1}$ or methacholine $\mathrm{PC}_{20}$ in the asthmatic patients. RP-HPLC of saliva and sputum samples revealed a single peak for both saliva and sputum corresponding to the elution point of the pure ET-1 standard. In both asthmatic and normal subjects the median (IQR) sputum level of ECP (129.0 (100-340) $\mu \mathrm{g} / \mathrm{l}$ and 340.0 $(134-710) \mu \mathrm{g} / \mathrm{l}$, respectively) was higher than the serum level of ECP, with serum ECP levels being higher in asthmatic subjects than in normal controls $(9.0(3-11) \mu \mathrm{g} / 1$ versus 1.0

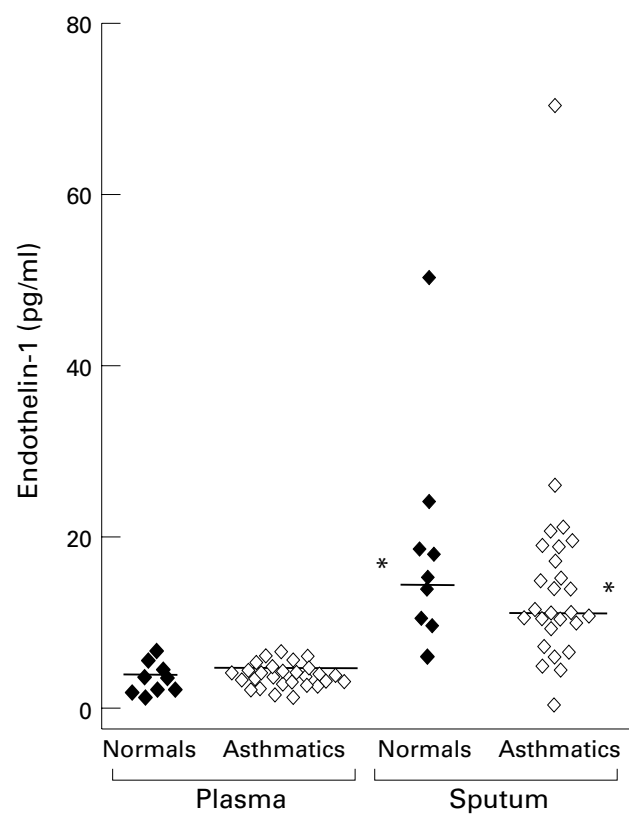

Figure 1 Plasma and sputum levels of endothelin-1 in normal $(n=9)$ and asthmatic $(n=28)$ subjects. Horizontal lines indicate median values. ${ }^{*} p<0.05$ sputum versus plasma levels.

$(0-7) \mu \mathrm{g} / \mathrm{l})$. Saliva levels of ECP were assayed in a subgroup of seven subjects drawn from each of the groups at random to compare with sputum. In this group the median (IQR) levels of ECP in the saliva $(10.0(5-69) \mu \mathrm{g} / \mathrm{l})$ were lower than sputum levels of ECP (210 (26-460) $\mu \mathrm{g} / \mathrm{l})$, suggesting that sputum levels of ET-1 do not represent salivary contamination.

\section{Discussion}

This study shows that it is possible to measure ET- 1 by RIA and to confirm its identity by RP-HPLC in sputum obtained by sputum induction, and that saliva and sputum levels of ET-1 are higher than plasma ET-1 levels in both normal and asthmatic subjects. Our findings for ECP would suggest that the levels of mediators present in sputum do not simply represent contamination from saliva. The finding that ET-1 levels are higher in saliva than in sputum is unexpected and its role in saliva is unknown. ET-1 has been measured in rat parotid gland and human saliva, ${ }^{4}$ although at lower levels than we observed. The finding of raised saliva levels of ET-1 also suggest that mediators which are being sought in sputum should also be assessed in saliva to avoid misleading results. Allowing, as far as can be determined, for dilution of bronchoalveolar lavage (BAL) fluid samples, our finding of sputum levels of ET-1 of $10-15 \mathrm{pg} / \mathrm{ml}$ accords reasonably with levels in BAL fluid found by other groups. ${ }^{25}$ Both these studies, however, reported an increase in the levels of ET-1 in the BAL fluid of untreated asthmatic subjects which we did not observe in our asthmatic group (nor in the subgroup taking inhaled $\beta_{2}$ agonists alone), although others have observed a fall in BAL fluid levels of ET- 1 at 04.00 hours in a group of patients 
with nocturnal symptoms ${ }^{6}$ which suggests that an increase of ET-1 levels in BAL fluid is not consistent in asthma. While the reproducibility and validity of sputum induction has been demonstrated, ${ }^{7}$ and cytokines and soluble factors can be measured in induced sputum, it should be noted that samples obtained by sputum induction are not identical to those obtained by BAL. ${ }^{8}$ The fact that ET-1 is present in sputum and saliva at levels higher than that in plasma suggests that ET-1 is produced or released locally within the respiratory tract, confirming work showing expression and secretion of ET-1 in a number of airway cells. ${ }^{1}$

It is not possible on the basis of the data presented to attribute any clear pathophysiological role for ET-1 in asthma, but it should be noted that patients were studied at rest, without prior bronchoconstriction. It is interesting to speculate that basal ET-1 levels may not reflect the situation in an acute exacerbation or following a bronchoconstrictor stimulus.

This study was supported by grants from the National Asthma Campaign (GC) and the Chest Heart and Stroke Association of Scotland (LT and KM). We also acknowledge the assistance of Dr JJ Morton of the University of Glasgow Department of Medicine and Therapeutics who performed the endothelin assays.

1 Vittori E, Marini M, Fasoli A, Franchis R de, Mattoli S Increased expression of endothelin in bronchial epithelial Rev Respir Dis 1992;146:1320-5.

2 Redington AE, Springall DR, Ghatei MA, Lau LCK, Bloom SR, Holgate ST, et al. Endothelin in bronchoalveolar lavage fluid and its relation to airflow obstruction in asthma. Am f Respir Crit Care Med 1995;151:1034-9.

3 Pin I, Gibson PG, Kolendowicz R, Girgis-Gabardo A, Denburg JA, Hargreave FE, et al. Use of induced sputum cel counts to investigate airway inflammation in asthma. Thorax 1992;47:25-9.

4 Lam HC, Takahashi K, Ghatei MA, Warrens AN, Rees AJ, Bloom SR. Immunoreactive endothelin in human plasma, urine, milk and saliva. I Cardiovasc Pharmacol 1991; 17(Suppl 7):S390-3.

5 Mattoli S, Soloperto M, Maurini M, Fasoli A. Levels of endothelin-1 in the bronchoalveolar lavage fluid of patients with symptomatic asthma and reversible airflow obstruction. $\mathcal{F}$ Allergy Clin Immunol 1991;88:376-84.

6 Kraft M, Beam WR, Wenzel SE, Zamora M, O'Brien RF, Martin RJ. Blood and bronchoalveolar lavage endothelin1 levels in nocturnal asthma. Am 7 Respir Crit Care Med 1994;149:947-52.

7 Pizzichini E, Pizzichini MMM, Efthimiadis A, Evans S, Morris MM, Squillace D, et al. Indices of airway inflammation in induced sputum: reproducibility and validity flammation in induced sputum: reproducibility and validity Care 1996;154:308-17.

8 Maestrelli P, Saetta M, Stefano A di, Calcagni PG, Turato G, Ruggieri MP, et al. Comparison of leukocyte counts in sputum, bronchial biopsies, and bronchoalveolar lavage. Am $\mathcal{F}$ Respir Crit Care Med 1995;152:1926-31. 